\title{
パズルマップ法によるミュージアムの内部空間の分析 \\ ANALYSIS OF THE INTERIOR SPACE IN THE MUSEUMS BY PUZZLE-MAP METHOD
}

\author{
高橋大輔* \\ Daisuke TAKAHASHI
}

\begin{abstract}
The purpose of this study is to clarify how people understands the structure of interior spaces.
Therefore, we developed new cognitive map " Puzzle-Map Method", and applied to the interior spaces of 7 typical planning museums.

As a result, it's very important to understand the interior spaces of museums that the clear structure from entrance spaces to derivational exhibition-spaces, being able to look out exterior spaces from interior spaces, effective relationships between elements and each space, and various spatial changing, i.e. open-ceiling, slope, skylight.
\end{abstract}

Keywords: Spatial structure of interior space, Cognition of the spatial structure, Puzzle-Map Method, Museums, Quantitative analysis

内部空間構成、空間把握、パズルマップ法、ミュージアム、数量的解析

\section{1. 研究の目的・概要}

近年の美術館・博物館・記念館といったいわゆるミュージアム文1、 注1)は、社会的要請の変化に伴い、従来の「文化施設」から展示品 や展示形態のプログラムの変化、利用者の様々な要望などに対応で きる機能を持った「文化情報施設」へと変わりつつある文1 3)。

これらの施設に要求される機能は、增大かつ複雑化し、来館者が 館内を観覧する際に、内部空間の構成を把握しにくい施設も多く、 設計・計画の際には「空間構成の個性と多様性」と共に「空間の分 かりやすさ」も極めて重要な点と考えられる。

そこで、本研究は「パズルマップ法による病院の内部空間の分析 一新しい認知マップ実験法の開発とその適用一」文4)において開発 された全く新しい認知マップ実験である「パズルマップ法実験」注2) （以下 P.MAP 法実験）を、ミュージアムの内部空間に適用するこ とにより、空間把握の構造を数量的に解析し、より分かりやすいミ ユージアムを計画する上での指針を得ようとするものである文5)(図 $-1,2$ )

なお、既往の研究として、柳澤忠・清水裕之氏ら文 6 )、奥平耕造 氏ら文7)、舟橋國男氏ら文8) が美術館・博物館の内部空間を対象と し、来館者の行動を基に動線計画に有用な資料を提供しているが、 観察調査による方法を用いており、来館者がミュージアムの内部空

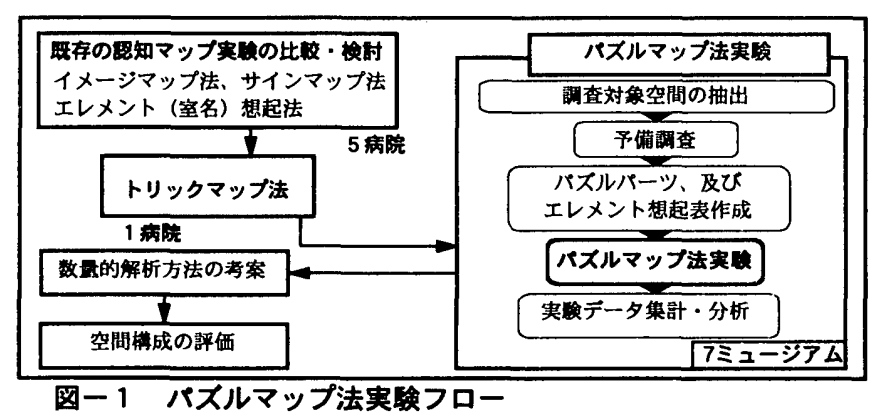

間の構成をどの様に把握しているか、イメージマップなどにより、 その具体的な建築 “空間” の構成と照らし合わせた上で、数量的な 分析を行った例は無い。

\section{P.MAP 法実鋻対象施設の選定}

ミュージアム施設に関する専門図書より、用途、規模、形態など を考虑して 100 館を収集し、(1)延床面積 (S: 〜1000 m、M:〜5000 $\mathrm{m} 、 \mathrm{~L}: 5001 \mathrm{~m} \sim$ ) 、(2)教地面積（S : $5000 \mathrm{~m} 、 \mathrm{M}: \sim 10000 \mathrm{~m}$ 、 $\mathrm{L}: 10001 \mathrm{~m} \sim$ ) 、(3)展示部分の階層（1層、2 層、3 層以上、ス キップ）、(4)平面形状（シンメトリー形、分棟形、プライマリー形、 不整形、プライマリー形同士の組み合わせ、不整形同士の組み合わ

* 国立小山工業高等専門学校建築学科 講師・博士 (工学) Lecturer, Department of Architecture, Oyama National College of Technology, Dr. Eng. 
せ、プライマリー形と不整形の組み合わせ・図-3)、(5)平面権成 (A：エントランスから廊下 $\rightarrow$ 展示室 $\rightarrow$ 廊下 $\rightarrow$ 展示室 $\rightarrow$ 廊下と館内 を一巡できる、B：ホール・吹抜・中庭と展示室が接している、C： エントランスから展示室 $\rightarrow$ 展示室と順に巡り、最初の展示室に戻る、 $\mathrm{D}$ : エントランスから椡形状に伸びた廊下が、各展示室に接続する、 $\mathrm{E}$ : エントランスから展示室 $\rightarrow$ 展示室 $\rightarrow$ 展示室と一巡することがで きる、F : 大空間で展示がされている、 $\mathrm{G}:$ エントランスから展示室 $\rightarrow$ 展示室 $\rightarrow$ 展示室と館内を巡るが別の出口から退館する、 $\mathrm{H}: \mathrm{A} \sim \mathrm{G}$ のいずれかが複合している・図-4)、(6)：企画展示か、常設展示 か、或いは両方を兼ね備えているかといった、上記 6 アイテムの 28 カテコリーを類似度としは 3)、最長距離法によるクラスター分析を 行った結果、虽合距蜼 80 付近で分けると、7タイプに類型化するこ とができ、それぞれの空間構成の特徽は次に示す通りである。

$\mathrm{C} 1$ : 展示室と展示室の間に廊下が存在せず、エントランスロピー から展示室 $\rightarrow$ 展示室 $\rightarrow$ 展示室と一巡する、C2：エントランスロビー から檴成の蚰となる廊下が、樹形状に枝分かれして配置されている ため、同一の廊下を行き来する展示形態である、C3 : 建物の中央部 に吹抜や中庭があり、その周りを囲むように展示室が配置されてい る、C4: 展示室と展示室の間に通過交通路として廊下があり、エン トランスロビーから廊下 $\rightarrow$ 展示室 $\rightarrow$ 廊下 $\rightarrow$ 展示室と一巡できる、C5 : 矩形空問の集合によって全体が権成されている、C6:比較的小さな 数地に建ち、左右対称形の空間構成である、C7 : 構成の軸となる廊 下や展示室の並びが複数存在し、それらが直行したり、不規則に交 わったりしている。

以上のような特徴を持つ 7 グループからそれぞれ栃木県立美術館、 千䓙婪立美術館、石水館、直岛コンテンポラリーアートミュージア 厶、東京都江戸東京博物館、大佛次郎記念館、笠間日動美術館の 7 ミュージアムを実踰対象として選出し、P.MAP 法実鈋を行った(表 $-1 、$ 図 $-5,6)$ 。

\section{3. パスルマップ法实卧の剭要}

ミュージアムの正しい平面図を垂れ壁や天井高、色彩、廊下幅、 明るさの変化などにより、1 つの空間のまとまりと感じられる単位 ことに切り放したもの 20 パーツ程度(パズルパーツ)をバラバラにし、 ランダムにパーツナンバーを貼り付けた上で、被険者に与え、パズ ルのように正しいと想う平面図を組立させるものである注4) 。

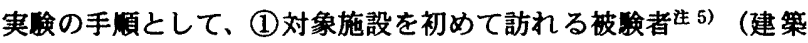
学科生 16 名) にエントランス $\rightarrow$ 展示部門 $\rightarrow$ エントンスといった来 館者の行動を基に、研究者側の案内人が予め決めた実検対象篹囲を 30 分程度案内し、さらに 30 分間、同筙囲内を被睮者に自由に歩き

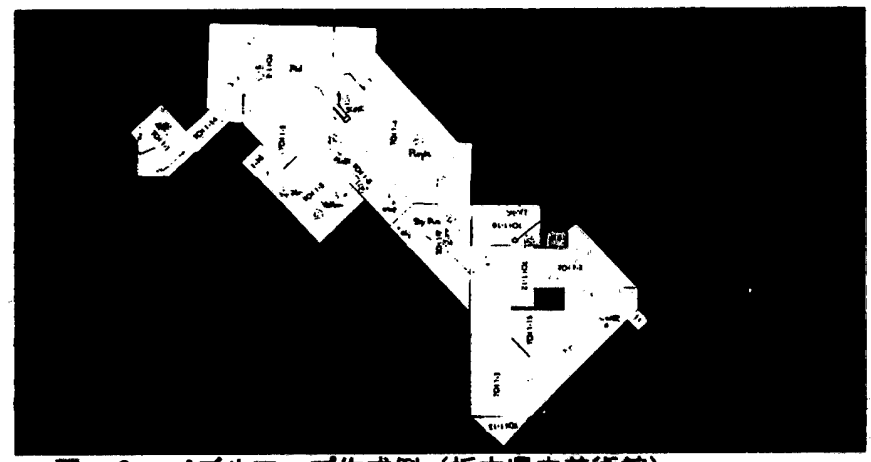

图ー2 パスルマッブ作成例（栃木県立美術官）

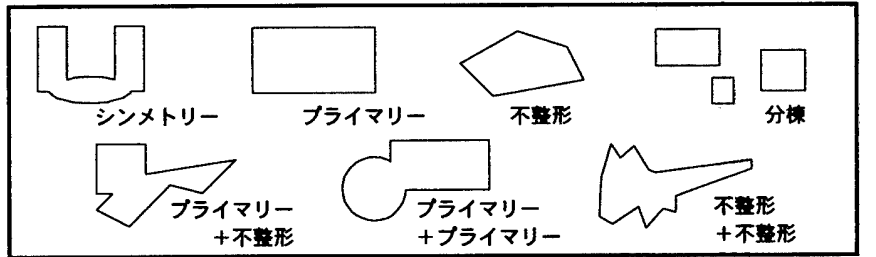

图一 3 平面形状の分類

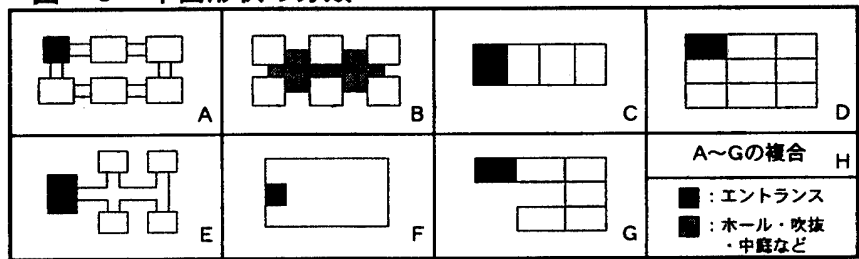

図-4 平面榑成の分類

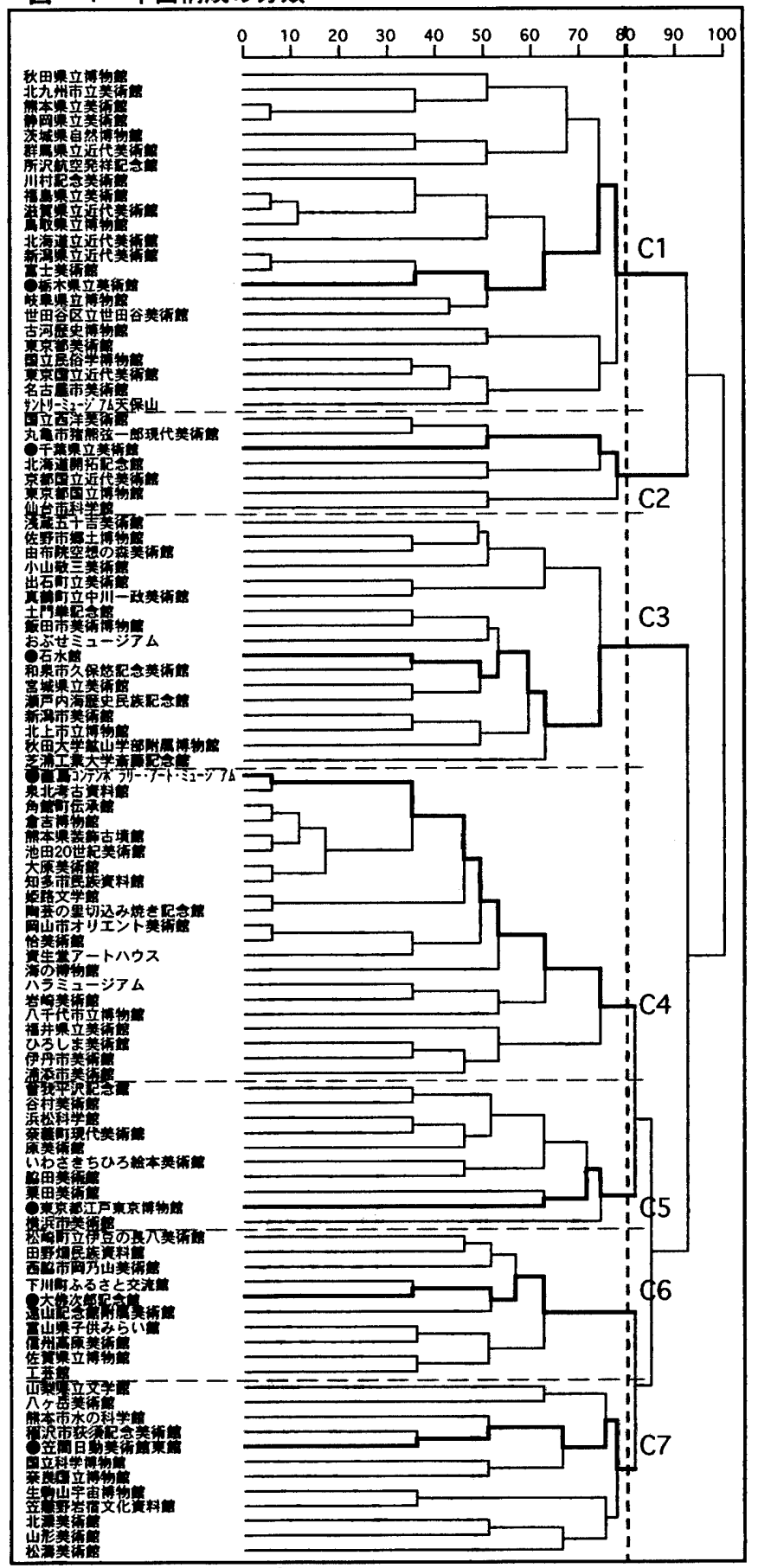

図ー5 パスルマップ法実跧対象ミュージアムクラスター図 
回ってもらう。(2)別室において、見学した際の記憶を基に、台紙の 上にパズルを組み立ててもらい、実験対象範囲の平面図を作成して もらう。(3)同時に、空間を再構成する時のパズルを組み立てる上で の判断基準となったものを何でも自由に書き込んでもらう。(4)空間 を把握する際、完成したパズル及び台紙上に、記境に残ったエレメ ント(もの)を自由に書き込んでもらい（自由エレメント想起法）、 さらに実験者側で指定したエレメント表を配布し、それらの位置を 書き込んでもらう（指定エレメント想起法）。これら(2)から(4)まで の一連の作業には 1 時間 30 分を与える。(5)さらに、正解図面の上 に(4)と同じ作業を 30 分以内で行ってもらう。

\section{4. 分析}

\section{1 分析方法}

実験で作成された P.MAP（以下完成 P.MAP）を正しい P.MAP （以下正解 P.MAP）とを比較し、実験の起点となるエントランス のパーツを KEY パーツ(以下 K)、通過交通路として次の空間につな がる廊下・展示室パーツを MAIN パーツ(以下 M)、行き止まりの展 示空間のパーツを main パーツ(以下 $\mathrm{m}$ )、階段室、トイレおよび行 き止まり空間のパーツを SUB パーツ(以下 S)と定めた上で、すべて 樹形図(図一7)に置き換え、空間同士の接続の仕方(フロー)として比 較し、どのように空間を把握しているか分析する。

分析の手順としては、(1)被験者が何を判断基準としてパズルで全 体の構成を組み立てていくか、台紙上に書き込んでもらった要素(も の)を集計し、各要素の合計を被験者数で割り、基準指摘率(\%)とし て算出する。(2)内部空間を構成しているエントランス・廊下・展示 空間・階段室・トイレといったパーツの有無を把握しているか、前 出の樹形図と比較した上で、各パーツの正答数を被験者数で割り、 パーツ正答率(\%)として算出する。(3)それらの空間が接続されていく 際に、個々のパーツがどの様な把握の間違い方をしているのか、夕 イプ別に分類・集計し、それぞれの合計を被験者数で割り、パーツ 接続誤答率(\%)を算出する。(4)完成 P.MAP、正解 P.MAPにおいて、 どの様なエレメント(もの)が想起されているのか、各想起エレメン トの合計をそれぞれ被験者数で割り、エレメント想起率を求める。 (1)、(2)、(3)、(4)の計算方法は以下の通りである。

\begin{tabular}{|c|c|c|c|c|}
\hline \multirow[t]{2}{*}{ • 基敏指摘率(\%) } & \multicolumn{4}{|c|}{$=$ バスルを組み立てる祭の基篗とした「もの」または「空間」 } \\
\hline & を指摘した人数 & ／ 被験者數 & $x$ & 100 \\
\hline ・パーツ正答率(\%)= & ஒ)= 各パーツの正答人数 & ／被酸者数 & $x$ & 100 \\
\hline ・バーツ接䌇 & \multicolumn{2}{|c|}{ 各パーツことの接続を間䢙えた人数 } & & \\
\hline 触答率(\%) & $=$ & / 被駧者数 & $x$ & 100 \\
\hline \multirow{2}{*}{$\begin{array}{l}\text { ・エレメント } \\
\text { 想起率(\%) }\end{array}$} & \multicolumn{2}{|c|}{ エレメントことの想起人数 } & & \\
\hline & $=$ & ／ 被瞼者数 & $x$ & 100 \\
\hline
\end{tabular}

また、パーツの有無や接綍の正誤については、樹形図と完成P.MAP を KEY 空間から MAIN、main、SUB 空間のフローについて、パ ズルマップ研究者 3 名が比較・検討した上で決定している。

これら(1)、(2)、(3)、(4)の分析方法を用いることによって、パズル で空間を再構成していく際に、どの部分が把握され易く、把握され

\begin{tabular}{|c|c|c|c|c|c|}
\hline & 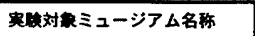 & 整地面棋( & 延床面艧 $(\mathrm{m})$ & 层示降/灌数 & 四查日 \\
\hline $\mathrm{Cl}$ & 栃木県立英䚘館 & 11,283 & 5,957 & $1-2 / 4$ & 97/07/03・睛 \\
\hline $\mathrm{C} 2$ & 千菜䢙立美術能 & 3,586 & 8,971 & $1 / 1$ & $97 / 06 / 18 \cdot$ 略 \\
\hline C3 & 石水饪 & 3,799 & 1,289 & $1 / 1$ & $97 / 07 / 18 \cdot$ 鮞 \\
\hline C4 & 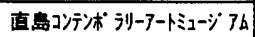 & 44,700 & 3,643 & $1-2 / 4$ & $96 / 11 / 18 \cdot$ 㥜 \\
\hline C5 & 東京部江戸東京博物馆 & 29,293 & 48,000 & $1,5-6 / 8$ & $96 / 11 / 15 \cdot 5$ \\
\hline C6 & 大佛次郎眍念馆 & 1,663 & 768 & $1-2 / 2$ & $96 / 12 / 06$ ·睛 \\
\hline C7 & 笠間日勤美術館 & 6,799 & 1,655 & $1-2 / 3$ & 97/07/03·酔 \\
\hline
\end{tabular}

表ー 1 実験対象ミュージアム施設概要
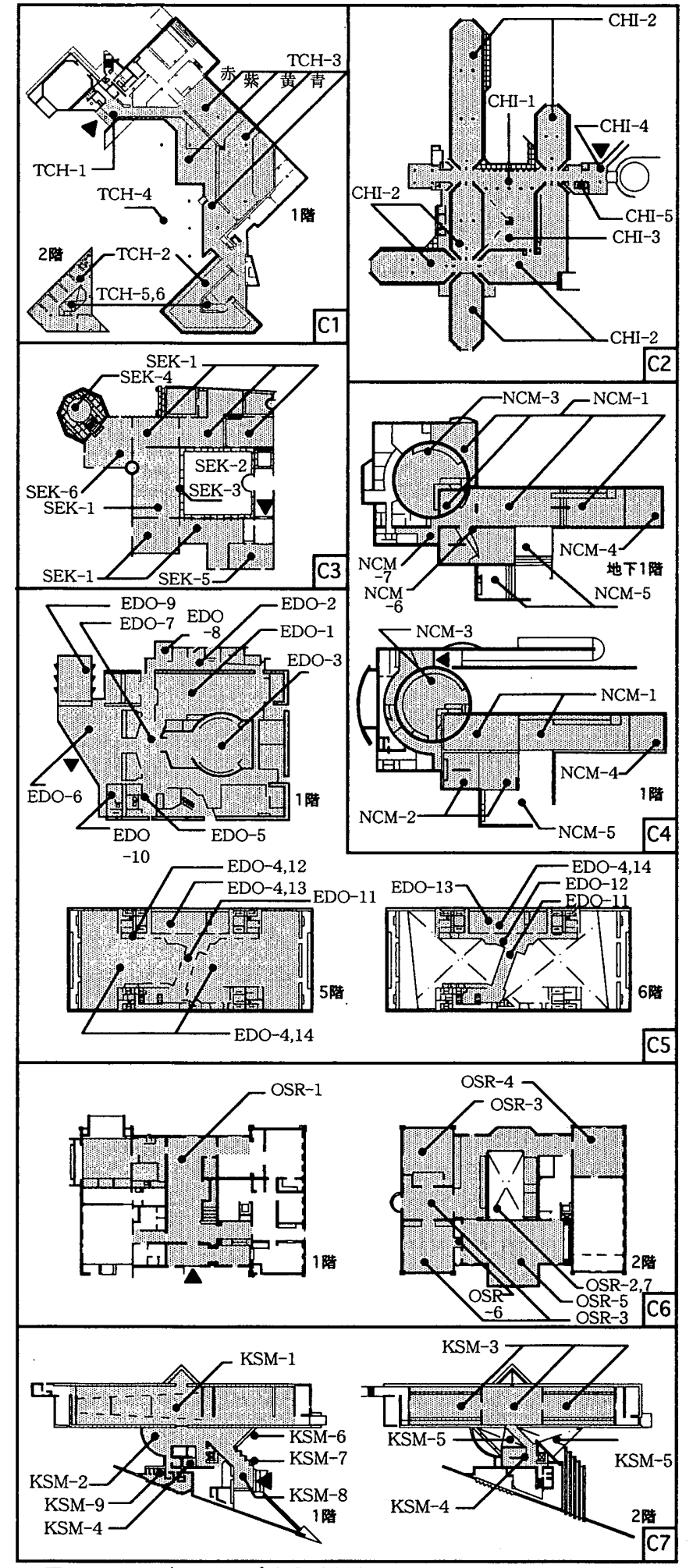

図ー6 パスルマップ法実験対象ミュージアム平面図 （ムはエントランス、網かけ部は実験対象空間） 
算いのか、どの様な正みが生じているか、何故その様な亜みが生じ るのか明らかにすることが出来る。

4. 2 P.MAP 法実跲結果における空間分析

<栃木渠立美術館>（因-6・C1）

1 陼に 2 雷吹抜のエントランスホール $(\mathrm{TCH}-1)$ と常設展示室 (TCH-2)、及び赤、紫、黄、青の 4 色の壁を持つ企画展示室(TCH-3) が小階段やスロープによるレベル差を持ちながら、屋外広場(TCH-4) を取り囲むように配置され、2 階に常設展示室(TCH-5)のみをもつ

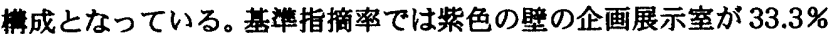
を示している（図-8）。これは、パズルを組み立てる祭の判断基 茟として、他の展示空间に比べ、極めて広い面糟を持ちながら企画 展示部門の中心的位褁にあり、さらに自由・指定エレメント想起率 で紫色の壁が 95.0\%を示していることから、この空間が非常に記㥁 に残りやすかったためと言える。

パーツ正答率では、常設展示部門にある階段(TCH-6)が $95.0 \%$ 、 エントランスが $67.5 \%$ と高い值を示しているが、これは 2 用の吹抜 (TCH-7)を共に有し、他の空間に比べ霞めて開放的な空間であるこ とから、非常に記愤に残りやすかったためと考えられる（図一-9）。

しかし、企画展示部門に関して自由・指定エレメント想起法では 壁の色が 87.5 100\%と非常に高い值を示しているが、パーツ正答 率では平均 $27.5 \%$ 、パーツ接繶誤答率では展示室パーツの取り连え やパーツ同士の接繶の間運いが $62.5 \%$ を示している。(図-10、11)

これは、4つの展示空間がそれぞれ特徽のある形態を持った空間 ではあるが、迷路状に各展示空間が接繶されているため、記憶に歪 みが生じ、把握されにくかったと言える。

<千莱県立美術館>（図-6・C2）

常設展示室の機能を持つ 1 本の愊の広い廊下空間(CHI-1)から企 画展示室(CHI-2)が桎状に派生した構成となっている。全体㩐成の ほぼ中央に位置する 2 同吹抜の展示ホール(CHI-3)が基淮指摘率で は 63.5\%、パーツ正答率でも $100 \%$ と極めて高い值を示している(図 -8、9)。これは、自由・指定エレメント想起率でそれぞれ 93.0\% の高い值を示す階段や吹抜・トップライトといった他の展示室には 存在しない空間に変化を与えるエレメントがあることから、非常に 記境に残りやすかったためと考えられる。また、常設展示室の機能 を併せ持つ釉下空間では、パーツ接続誤答率でパーツの取り違えが 100\%と非常に高い值を示している。これは、この空間の天井高が 高いのに対し、開口部が低い位置にあるために非常に暗く、接する 2 展吹抜の展示ホールのスケールが非常に大きいことから、廊下の 幅に至みが生じ、実際の空間よりかなり狭く把提されたため、と考 えられる。企画展示部門では、各展示空間が橵状に派生しており、 ぞの空間も穿囲気が非常に似ており、それぞれを特街ゔけるエレメ ントも存在しないことから、パーツの取り逞えが $87.0 \%$ と高い值を 示している（図一10）。

自由・指定エレメント指摘率では、やはりエントランス (CHI-4) から常設展示部門入口の受付カウンター(CHI-5)や家具、展示品が 40〜100\%の值を示し、企画展示空間では展示品以外指摘されてい ない。

〈石水館〉（図-6・C3）

常設展示室(SEK-1)が池(SEK-2)を取り囲むようにコの字型に配 置され、それぞれの展示室から池を望むことが出来る粠成となって

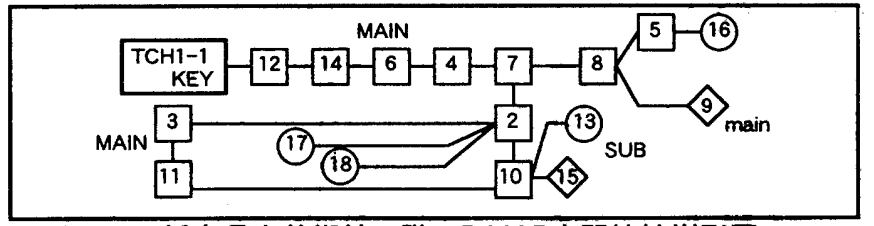

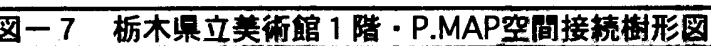

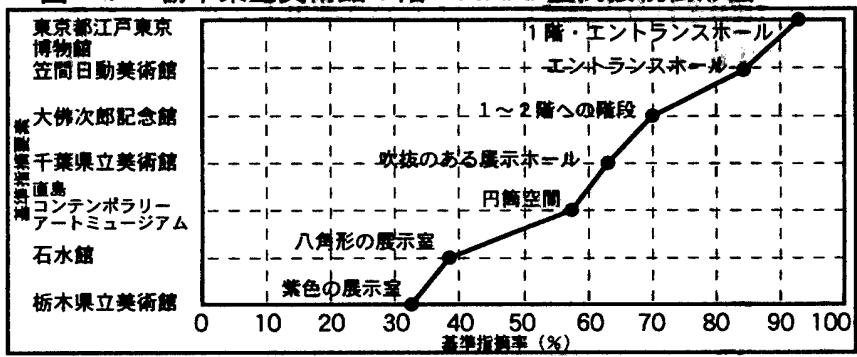

図ー8 基準指摘毫（各ミュージアム最大住のみを抽出）

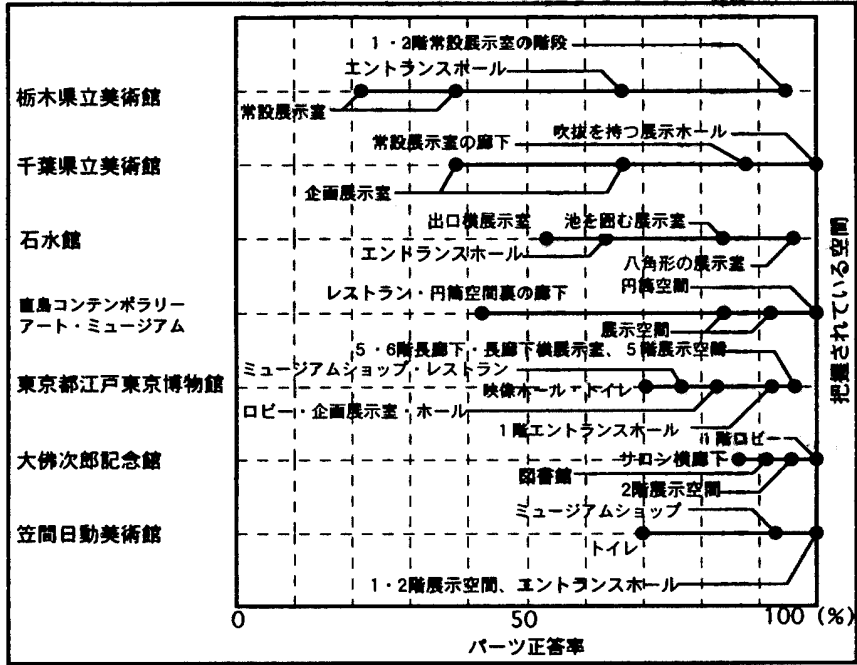

図ー9 パーツ正答率

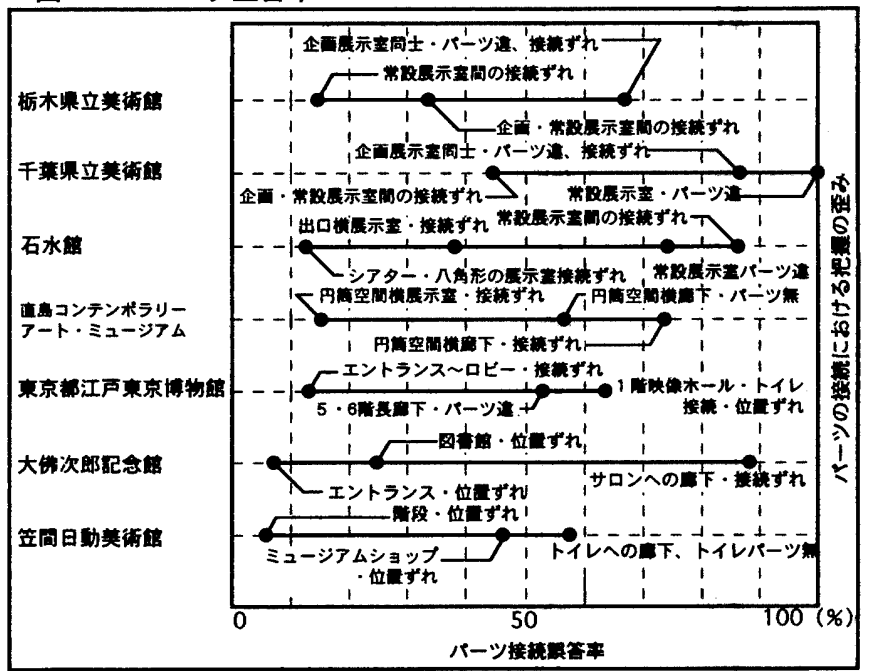

图ー10 パーツ接暁篹答率

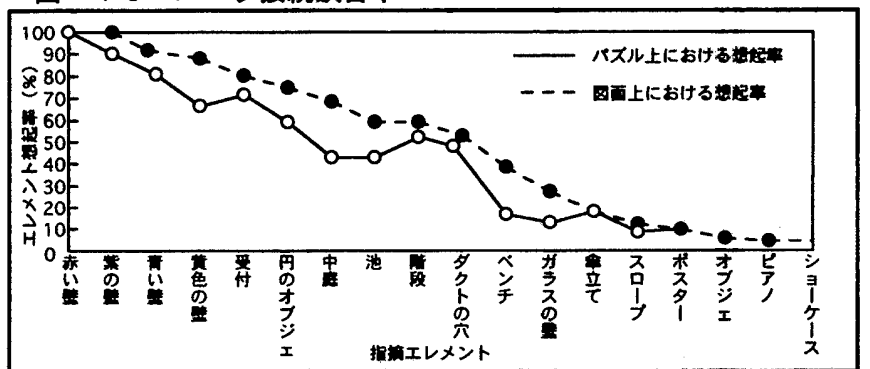

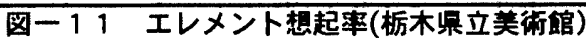


いるが、実際の空間では直射日光から展示品を守るため、開口部 (SEK-3)はカーテンで遮られており、池は見えない。それらの展示 室からずれた位置に接䌇している八角形の展示室(SEK-4)は、基準 指摘率が $38.0 \%$ と最も高く、パーツ正答率が $96.0 \%$ と極めて高い值 を示している。これは、他の展示室が矩形で構成されているのに対 し、この空間がそれらとは全く異なった八角形という形態であり、 自由・指定エレメント想起率で $87.5 \%$ を示す御影石貼りの床といつ た他の空間には無い特徵的なエレメントをもっていることから、非 常に記憶に残りやすかったためと言える（図-8、9）。

常設展示空間では、全体の構成がコの字型であることは把握され ており、パーツ正答率も 63.2 96.0\%を示しているが（図-9）、 壁面の素材や天井高が均一であり、空間的変化が少ないことから、 記憶に丕みが生じ、パーツ接続誤答率で展示室間のパーツの接綍ず れは平均 $72.6 \%$ と非常に高い值を示している（図-10）。また、自 由・指定エレメント指摘率では、エントランスの受付カウンター (SEK-5)が 97.5\%、八角形の展示室に隣接するミニシアターのスク リーン(SEK-6)が 92.5\%、池の噴水が $92.5 \%$ と極めて高い値を示し ているが、やはり常設展示空間では展示品以外のエレメントは指摘 されていない。

〈直島コンテンポラリーアートミュージアム〉（図-6・C4）

地下 1 階に常設 $(\mathrm{NCM}-1) \cdot$ 企画展示室(NCM-2)、1 階に常設展示 室(NCM-1)が配置されており、円筒状の吹抜空間のスロープによっ て展示室間を移動する構成である。この円筒空間(NCM-3)は基準指 摘率（図-8）で 57.5\%、パーツ正答率（図-9）でも 100\%と非常 に高い値を示している。これはこの空間が他の空間に比べ非常にヴ オリュームが大きく、スロープ・トップライト・階段といった空間 を演出するための装置が存在していることから、非常に記憶に残り やすかったためと考えられる。このため、これらの 3 エレメントは 自由・指定エレメント指摘率でも全て $97.5 \%$ を示している。また、 各展示室も光庭(NCM-4)やテラス(NCM-5)といつた外部空間に面し ており、非常に明るく、展示室空間全体を見渡すことが出来るため、 パーツ正答率は 82.5 92.5\%と極めて高い值を示している (図-9)。 しかし、円筒空間の外側に配置されているレストランの入口(NCM-6) や弧を描く廊下(NCM-7)は、他の空間に比べ幅が狭く、開口部が存 在せず、ダウンライトのみの暗い空間となっている。その上、エレ メントが全く存在しないことから、この部分の空間構成を把握しに くく、パーツ正答率が $42.8 \%$ 、パーツ接続誤答率ではパーツが存在 しない、パーツ同士の接続のずれといった間違いが、それぞれ $57.2 \%$ 、 74.5\%を示していると考えられる（図－9，10）。

<東京都江戸東京博物館>（図一6・C5）

1 階に企画展示(EDO-1)・ミュージアムショップ(EDO-2)・シア ター(EDO-3)、5・6 階が常設展示空間(EDO-4)となっており、工 レベーター(EDO-5)で $1 \rightarrow 5$ 階、階段で $5 \rightarrow 6$ 階を移動する構成で ある。1 階の基準指摘率では、エントランスホール(EDO-6)が $92.5 \%$ と極めて高い値を示している（図一8）。これは、この空間から接 綍する空間を全て見通すことができるため、パズルを組み立てる際 の判断基準となったものとして指摘されたと言える。そのため、こ の空間から派生するロビー(EDO-7)、ミュージアムショップ(EDO-8)、 企画展示室、シアターといった全体の骨格をなす空間はパーツ正答 率で平均 $82.4 \%$ を示しており、非常に把握しやすかったと言える(図
-9)。それに対し、エントランスホール内にある映像ホール(EDO-9) やトイレ(EDO-10)でパーツ接䌇誤答率のパーツの位置のずれが 64.7\%を示しているのは、自由・指定エレメント指摘率において、 これらの周囲に存在するものは全く想起されていないことから、空 間の接続する位置を把握し難かったためと考えられる（図一10）。

5 ・ 6 階の基準指摘率では日本橋(EDO-11)が $24.0 \%$ を示してい る（図-8）。これは大空間の中心に配直されており、他の展示物 に比ベ、非常にシンボリックであるためあるため、この空間をパズ ルを組み立てる際の判断基淮とすることで、自分のいる位置やそれ ぞれの展示室との位置関係を把握できると言える。そのため、パー ツ正答率では、長廊下(EDO-12) 、長廊下に接続する展示室 (EDO-13)、展示空間(EDO-14)が全て 94.0\%と極めて高い值を示し ていることから、全体の空間構成は、殆ど把握できているといえる (図-9）。しかし、日本橋は床面にむくりがついており、長廊下 は廊下幅が広く天井高の極めて高いことから、別のパーツを用いる ことで実際の空間よりも長く把握している。そのため、パーツ接䌇 誤答率ではパーツの取り違えが共に53.2\%を示している（図-10）。 自由・指定エレメント指摘率では、これらの空間内の所々に配置 されているベンチの指摘率が $77.0 \%$ と高い値を示している。 <大佛次郎記念館 $>($ 図 $-6 \cdot \mathrm{C} 6$ )

1 階は 2 層吹抜のホールを兼ねた常設展示室(OSR-1)、2 階はそ の吹拔(OSR-2)を取り囲むように常設展示室(OSR-3)や図書館 (OSR-4)が配置された構成となっている。このミュージアムの場合、 他に比べ非常に規模が小さいことから、全体の空間構成は把握され ている。基準指摘率では 1 〜 階への階段が 70.0\%を示しているが、 これは、全体の空間構成の中心に位置し、各展示室や郎下がそこか ら派生しているためと考えられる（図一8）。

ロピー、展示ギャラリーなど主要諸室については、平均 $96.5 \%$ の 非常に高いパーツ正答率（図一-9）を示す一方で、パーツ接䌇誤答 率 (図-10)でサロン(OSR-5)の左側と展示室をつなぐ通路(OSR-6) のパーツが存在せず $89.3 \%$ 示しているのは、この通路は他の空間 に比べ、天井高が低く開口部のない暗い空間であるため、記憶に残 り難く、把握に歪みが生じたと考えられる。自由・指定エレメント 想起率では、ステンドグラスを用いたロビーのヴォールト天井 (OSR-7)や展示室内に置かれた調度品、猫をモチーフにした照明器 具が平均 $97.5 \%$ と極めて高い値を示している。これは、全体を構成 している各々の空間は変化が少ないことから、装飾されたエレメン トが指摘されたと言える。

〈笠間日動美術館〉（図-6・C7）

1 階に企画展示(KSM-1)・ミュージアムショップ(KSM-2)、2 階 に常設展示室(KSM-3)を備えており、階段(KSM-4)で 1 〜 階を移 動する構成となっている。吹抜(KSM-5)や前庭(KSM-6)に面した大 開口部(KSM-7) といった空間的な変化を持つエントランスホール (KSM-8)は、基準指摘率 86.0\%、パーツ正答率 100\%と高い值を示 している（図-8，9）。これは、この空間に接続する展示空間への 構成が明快であり、前出の大開口部があることで明るいため、非常 に記檍に残りやすかったためと考えられる。

また、1・2階の各展示室間も視線を遮るものが全く存在せず、 見通せることが出来ることから、パーツ正答率が $100 \%$ と極めて高 い（図-9）。しかし、エントランスホールや展示室から全く見通 
すことの出来ないトイレ(KSM-9)は、他の空間のボリュームが非常 に大きいのに対し、廊下幅が㹟く、開口部の全く無い廊下の奥まっ た位貫にあることから把握が困難になり、パーツが存在せず、パー ツ接繶棓答率が $58.5 \%$ を示している（図-10）。また、自由・指摘 エレメント指摘率では、エントランスホール・展示室内のエレメン トは数多く指摘されているが、トイレ周りの空間では何も指摘され ていない。

\section{5. 具回带分析}

5. 1 P.MAP 法実険結果のパズル完成度評価

被挽者に作成された P.MAP の完成度は、空間棰成をどの位把握 しているのかを数值化したものとして捉えることが出来る。

そこて、全ての完成 P.MAP について、どの程度正解 P.MAP と 合致するか、4 段階に分けて「P.MAP 完成度評価法」を行った(図 一12)。この評価方法で得られた值は、「空間梓成の把握のしやすさ」 を示す尺度であるため、以下の評価実験・分析を行った。

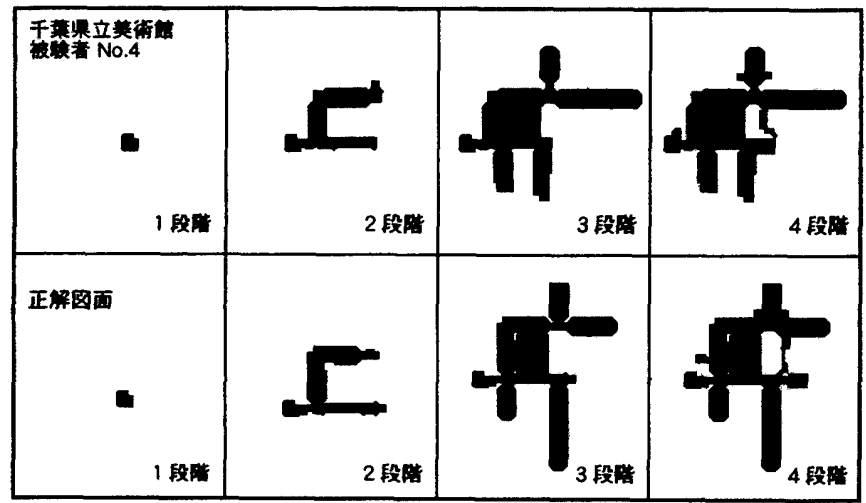

图ー12 P.MAP完成度評価法・呈示サンプル(千菜紧立美術馆)

この評価方法は全ての完成 P.MAP をパズルの貼り方や、丁掌さ、 微妙な歪みなどの個別的差異を一律化するために、CADによって描 き改めたものを用いて、 $\mathrm{K}$ のみ示したものをく 1 段階〉、 $\mathrm{K}+\mathrm{M}$ を 示したものをく 2 段階 $>、 \mathrm{~K}+\mathrm{M}+\mathrm{m}$ を示したものをく 3 段階〉、全 パーツを示した完成されている状態をく4段階〉として、それぞれ の段階に応じたミュージアムの正解 P.MAP を 100 点とした上で、 各完成 P.MAP を机上に並べ、点数で評価してもらう方法である。

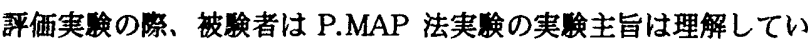
るが、れに掃わらなかった建築学科生 15 人によって行った。

その結果、く1段階〉においては、ほとんどの被検者が正解に近 く、評価に差はみられなかったが、く2段階〉では、始発空間であ る KEYに接綍しているパーツや MAIN パーツ同士の接経に堽みが 生じていることから、1 段階に比べて低い值を示している。<3 段 階〉、く4段階〉では、全体の樓成がほぼ决定づけられるためにSUB が接続しても評価值に大きな変化はみられなかった。

そこで、以後の分析には、4 段階目の評価 $\left(\mathrm{Y}_{4}\right)$ を用いることに した。

\section{2 パーツ構成種類別による重回尖分析}

「空間檴成を把握する際に稆みを生じさせる要因」が「空間棬成 の把握のしやすさ」に及ぼす影棎るため、前述の分析過程にお いて作成したフローを基にして、各ミュージアムの完成 P.MAP に おける全てのパズルパーツの接続状態を比較・検討した。
その結果、実険対象空間の構成を把暒する祭、昰みを生じさせる 要因のパターンが、(1)存在すら把握できない空間、他の空間の流れ から全く切り放された不連続な空間がある、(2)形黛や大きさの類倒 し、各々特徽の欠如した空間が何種か存在する、(3)空間の接合点の 分岐、または交差が暖昧である、(4)空間の方向性が欠如している、 (5)空間の形熊が䁔昧である、の5タイプに分類されることが分かっ た。そこで、これらの要因がパズルパーツの接䌇の仕方として、順 にX1：パーツが存在しない、X2: パーツの選択を譟った、X3: パー ツの接綍位置が连う、X4：パーツの接続向きが違う、X5：余分な パーツを接䌇させている、に対応していると考えられることから、 この 5 カテゴリーについて、空間同士の接紿の仕方を集計する。

次に、X1〜X5 までの累計を各ミュージアムの総パーツ数で割り、 百分率とした値を説明変数、4 段階目の評価 $\left(\mathrm{Y}_{4}\right)$ を目的変数とし

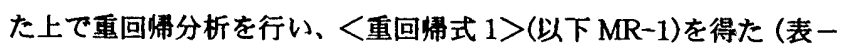
2).

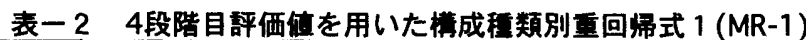

\begin{tabular}{|c|c|c|c|c|c|c|c|c|}
\hline 呼晌 & \multicolumn{2}{|c|}{$\begin{array}{l}\text { パーツか } \\
\text { 存在しない }\end{array}$} & 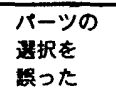 & \multicolumn{2}{|c|}{ 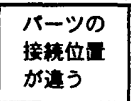 } & 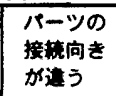 & \multicolumn{2}{|c|}{$\begin{array}{l}\text { 余分な } \\
\text { 倿ーツか } \\
\text { 接模している }\end{array}$} \\
\hline$Y_{4}=$ & \multicolumn{2}{|c|}{$-0.46 X_{1}$} & $-0.19 X$ & \multicolumn{2}{|c|}{$-0.16 \mathrm{X}_{3}$} & $-0.12 X$ & \multicolumn{2}{|c|}{$\begin{array}{r}-0.45 X_{5} \\
+92.3 \\
\end{array}$} \\
\hline 重相閣 & & 0.7 & & 係数 & & 0.63 & 定数項 & 92.3 \\
\hline
\end{tabular}

この結果、各カテゴリーのウエイトは、X1、X5 が-0.46、-0.45 と他の 3 カテゴリーよりも高い値を示しており、 $\mathrm{M}$ となる展示空間 が通過交通路としての機能を兼ね、他の空間に比べてスケールが大 きいため、あるべきパーツがなかったり、余分なパーツが接䌇され ている罚合には、全体の空間構成を全く変えてしまうため、評便を 大きく下げてしまう要因であることが分かる。また、X2、X3、X4 は、 $-0.19 、-0.16 、-0.12$ と他の 2 カテゴリーに比べ低い值を示し ているのは、極端に形状の違うパーツがこれらの3カテコリーにお いて間違いが生じていない限り、全体の空間構成が大きく変化しな いためと言える注6)

\section{3 パーツ接続種類別による重回帰分析}

次に、「 $\mathrm{K} 、 \mathrm{M} 、 \mathrm{~m} 、 \mathrm{~S}$ 空間のつながりにおける把握の歪み」 が「空間構成の把握のしやすさ」に及ほす影整を探るため、まず、 完成 P.MAP のパーツ接綂について、 $K 、 K+M 、 K+m 、 K+S 、 M+M 、$ $\mathrm{M}+\mathrm{m} 、 \mathrm{M}+\mathrm{S}$ の 7つの接続種類に分類した。その上で、これらを前 出の 5 カテゴリーについて累計し、各ミュージアムの接綍種類別パー ツ数で割った百分率の值を MR-1に代入した。

その上で、これらを前出の 5 カテゴリーについて照計し、各ミュー ジムの接続種類別パーツ数で割った百分率の值を MR-1に代入し た。その結果、得られた各接䌇種類別の得点を説明変数、4 段階目 の評価 $\left(\mathrm{Y}_{4}\right)$ を目的変数とした上で重回㷌分析を行い、<重回师式 $2>$ (以下 MR-2) を得た (表-3)。

表一3 4段階目評価侹を用いた接続程類別重回为式2(MR-2)

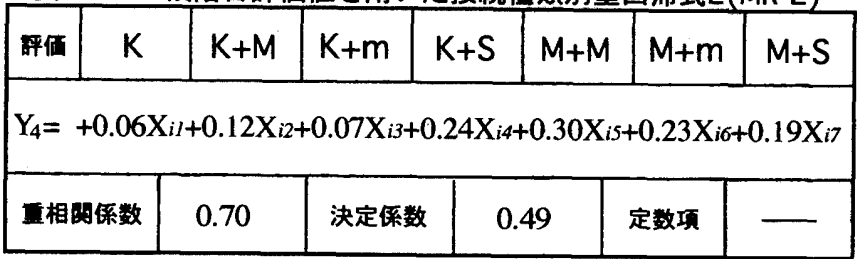


この式の係数は、全サンプルにおける接䌇種類別の間違いを示す ウエイトとなる。

MR-2では、Kが 0.06 と低い值を示している生7)。これは、Kが 始発空間であるため、非常に記憶に残りやすく、把握の歪みも少な いために、このような値が得られたと考えられる。

また、 $\mathrm{M}+\mathrm{M} 、 \mathrm{M}+\mathrm{m} 、 \mathrm{M}+\mathrm{S}$ が順に $0.30 、 0.23 、 0.19$ を示してい るのは、ミュージアム空間では、 $\mathrm{M} や \mathrm{~m}$ が全体空間の構成をほぼ 決定づけているために、展示室同士のつながりを誤つて把握すると、 接続する空間の把握にも歪みが生じるからといえる。また、 $\mathrm{K}+\mathrm{S}$ が 0.24 とこの中で高い值を示しているが、これは K に接綂する S に 特徵のある空間が少ないことから、記憶に残りにくく、把握しにく いためと考えられる注7)。 $\mathrm{K}+\mathrm{M} 、 \mathrm{~K}+\mathrm{m}$ の係数が $0.12 、 0.07$ と低い 值を示すのは、始発空間である K をほぼ認識してるために、そこか ら派生する $\mathrm{K}+\mathrm{M} 、 \mathrm{~K}+\mathrm{m}$ の接䌇も正しく把握されたためと考えられ る注7)。

5. 4 重回帰分析結果による接続種類別の得点化

MR-2 を求める方法と同様に、接続種類ごとのウエイトを算出し、 全てのミュージアムで比較しやすいように基準化を行い、接続種類 別の平均を求めた（表一4）。

表 -4 接続種類別平均得点

\begin{tabular}{|c|c|c|c|c|c|c|c|}
\hline & $K$ & $K+M$ & $\mathrm{~K}+\mathrm{m}$ & $\mathrm{K}+\mathrm{S}$ & $M+M$ & $M+m$ & $M+S$ \\
\hline 栃木昶立美術館 & 17.0 & 14.2 & 7.2 & 7.2 & 9.0 & 8.2 & 3.9 \\
\hline 千筆県立美術领 & 28.5 & 28.5 & & 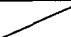 & 5.7 & 8.8 & 28.5 \\
\hline 石水館 & 20.1 & 20.1 & & 20.1 & 5.3 & 14.2 & 20.1 \\
\hline 面岛ミューシアム & 26.4 & 26.4 & 6.9 & 14.6 & 2.5 & 7.5 & 15.8 \\
\hline 江戸東京博物館 & $\overline{33.6}$ & 24.5 & & 12.3 & 11.8 & 8.6 & 9.3 \\
\hline 大佛次郎諨念館 & 29.3 & 25.1 & & 14.5 & 6.6 & 9.2 & 15.3 \\
\hline 䇫間日動美征館 & 26.7 & 26.7 & & 13.4 & 15.8 & 9.1 & 8.3 \\
\hline
\end{tabular}

この結果、 7 ミュージアムにおける 4 段階目 $>$ の接続種類別平 均得点の傾向は次に示す 3 つに大別できると言える。

(1)枋木県立美術館や笠間日動美術館のように、 $\mathrm{K} 、 \mathrm{~K}+\mathrm{M}$ が高い値を 示し、次いで $\mathrm{M}+\mathrm{M} \rightarrow \mathrm{M}+\mathrm{m} \rightarrow \mathrm{M}+\mathrm{S}$ と值が低くなる場合には、 $\mathrm{K}$ か ら $\mathrm{M} へ$ へ空間を見通すことが出来るが、 $\mathrm{M}$ ・ S の空間が実験起点 から離れた位置、または開口部のない暗い位置にあるため、それら の構成を把握しにくくなっていることを示している。そのため、 $\mathrm{K}+\mathrm{M}$ や $\mathrm{K}+\mathrm{S}$ も $\mathrm{M}+\mathrm{M}$ より低い值を示すこととなる。

(2)千萧県立美術館、石水館、直島コンテンポラリーアートミュージ アム、大佛次郎記念館のように $\mathrm{K} 、 \mathrm{~K}+\mathrm{M}$ が極めて高い值を示し、 $\mathrm{M}+\mathrm{M} \rightarrow \mathrm{M}+\mathrm{m} \rightarrow \mathrm{M}+\mathrm{S}$ と値が高くなる場合には、 $\mathrm{K}$ とそれに接䌇す る $\mathrm{M}$ 空間は吹抜・トップライト・中庭などを持つため、非常に把握 しやすいが、次に接続する $\mathrm{M}$ 空間がいくつかに分岐しているため、 それらの空間構成を把握する際、歪みが生じることを示している。 しかし、 $\mathrm{M}+\mathrm{m} \cdot \mathrm{S} 、 及 ひ ゙ ~ \mathrm{~K}+\mathrm{m} \cdot \mathrm{S}$ の空間構成は非常に明快であ ると言える。

(3)東京都江戸東京博物館のように、 $\mathrm{K} 、 \mathrm{~K}+\mathrm{M}$ が非常に高い值を示し、 $\mathrm{K}+\mathrm{S} 、 \mathrm{M}+\mathrm{M} \rightarrow \mathrm{M}+\mathrm{m} \rightarrow \mathrm{M}+\mathrm{S}$ と低い值を示していく場合には、 $\mathrm{K}$ が 極めてスケールの大きい特徵を持った空間であるため $\mathrm{K} \rightarrow \mathrm{M} \rightarrow \mathrm{m} 、 \mathrm{~S}$ と進むにつれ、廊下幅や天井高といった空間のスケールが次第に小 さくなり、大空間の印象が非常に強いことから、記憶に残りにくく、 パズルで空間を再構成する際、䙵みが生じることを示している。

\section{6. まとめ}

病院の空間把握の研究において開発した全く新しい認知マップで ある「P.MAP 法実験」をミュージアム空間に適用した結果、イメー ジマップやサインマップの問題点である表現能力の個人差を問題と せずに文4)、建築の内部空間における空間把握構造を探ることが出 来、重回帰分析を用いた解析方法を適用することによって、ミュー ジアム施設の内部等間の把握構造を数量的に明らかにすることが出 来た。

P.MAP 完成度評価法、重回帰分析など一連の分析結果から、実 験の始点空間となる K から接続する $\mathrm{M} 、 \mathrm{~m} 、 \mathrm{~S}$ 空間を把握できる明 快な構成が、全体の空間を把握する際に非常に重要であることが分 かり、単純な構成の空間だけが把握を容易にするのではなく、 $\mathrm{K} 、$ $\mathrm{M} 、 \mathrm{~m} 、 \mathrm{~S}$ の空間の接続の仕方、それぞれの内部空間からの外部空 間の見え方、中庭・吹抜・トップライト・スロープ・円弧を描いた 壁を用いた空間の変化が重要であり、家具や展示品といったエレメ ントの効果的な配置を加えることによって、空間の変化や構成要素 が多様である内部空間であっても、よりわかりやすい空間を造り出 せることが分かる。設計・計画上の要点は次に示す4つにまとめら れる。

(1)来館者が館内を回るための始発空間であるエントランスホール、 いわゆる $\mathrm{K}$ 空間から接続する $\mathrm{M} 、 \mathrm{~m} 、 \mathrm{~s}$ が視覚的に連䌇性を持つこ とで全体の空間粠成を把㨋しやすくなる。(2)吹抜・トップライト・ ハイサイドライト・スロープ・ヴオールト天井・大開口部といった 建築的演出により、空間の流れに変化を与えることで、さらに分か りやすい空間䊈成を作り出す。(3K、M、m、S から開口部を通して、 中庭や庭園、池といった外部空間が見えることで、各々の空間の用 象が強くなるため、全体の空間を棈成しやすくなる。(4)キーエレメ ントがエントランス・各空間の接縝部・行き止まりの開口部の無い 空間に存在し、それぞれの空間の形態や構成と呼応することで、全 体の空間構成を把握する際、効果的な影響を及ぼす。

本研究に当たっては、東京電機大学工学部建築学科 船越徹教授、 積田洋講師に御指導いただき、当時大学院生であった田島理恵氏に 実験・分析の協力を得た。また、実験に協力していただいた各ミュー ジムの関係職員の方々に心から深く感謝いたします。

\section{〈各考文献〉}

文 1）岡野圂著、彰国社編 : ミュージアム図鑑 博物館・美術館・資料館の魅 力と吸引力 建策文化 9 月号別冊、彰国社、pp.7〜21、1996

文2）戸尾任宏、仙田満著、船越徽編 : Space Design Series 3 美術館・博 物館、新日本法規、1996

文 3 ）美術出版社編：美術手帖 生きている美術館、美術出版社、1996.5

文 4）船越徹、積田洋、高橋大輔 : パズルマップ法による病院の内部空間の 分析一新しい認知マップ実呀法の開発とその適用一、日本建築学会計画 系論文報告集、pp129 136、第 503 号、1998.1

文 5）船越徹、積田洋、高橋大輔、田島理惠他：美術館・博物館の空間棈成 に関する研究(その 1 3)、日本建築学会大会学術謐演梗概集、pp.391 〜396、 1997.9

文6）柳澤忠、清水裕之、鉿木賢一他：博物館展示空間の環境評価に関する 研究、日本建築学会大会学術諈演梗溉集、pp.621 622、1994.9

文 7) 奥平耕造他：美術館における爁賞動線について、日本建築学会大会学 術講演梗概集、pp.433 434、1995.8

文 8）舟橋國男、奥俊信、小浦人子、木多道宏他：美術館利用者の館内行動 に関する観察調查、日本建管学会大会学術陆演梗概集、pp.383 384、 1997.9 
<注㴶〉

注 1）一般に博物館・美術館・資料館・展示館・記念館と呼ばれる施設があ るが、必ずしも明磪な定義があるわけではない。ここでは類似施設も 含め、総称してミュージアムと呼ぶ。

注 2)この P.MAP 法は、被者がそれぞれ共通に与えられた単純な形状の パーツを用いて、把握した対象施設の空間構成を並べていくのみであ るため、イメージマップやサインマップの問題点である表現能力の個 人差を問題としないで斎むこと、作成された P.MAP を得点化し、重回 帰分析を適用することにより数量的解析が可能である、といった利点 がある。

注 3）調查対象ミュージアム選出の陓、クラスター分析を用いているのは、 6アイテムの 28 カテコリリーにおける「共通性」と「違い」から、似 た物同士をクラスターとしてまとめていくことにより、その関係を榯 形図として明らかにし、タルーブとして分類・類型化することで、客

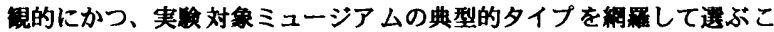
とが出来るためである。

また、対象ミュージアムのアイテムカテゴリーを分類する腺には、機珹 的に䬶当するカテコリリーを全て選択している。

注 4) パズルパーツを 20 パーツ程度としたのは、全パーツが 10 パーツ程度 と少ない埸合には各々の空間を機能や特改別にパーツとして切り出す ことが覲しく、30 パーツ以上になると、空間が意味もなく紐分化され、 パーツ数が多いため、被膜者の疲労度が高まり、空間把㩧の信頼性を 低くするためである。また、各パーツにはランダムにナンバーが貼り 付けられており、実䄼の始点となるパーツにはNo.1 と示されている。 また、文 4)に示す病院の研究では、パーツ数を 20 程度とし、パーツ ナンバーをパーツの表褁両面に貼り付けていたが、この埸合でも被 者の波労度が高まる煩向が見受けられたため、実䮦方法を再検討した 結果、ミュージアム施設ではパズルパーツの片面のみにパーツナンバー を貼り付けることとした。
注 5）一般の人々を被嗆者とする埸合には、来訪歴の有無、年蛉による認知 能力の差、実硂時間の拘束、費用といった問題があり、建筑学科生と した。被䀢者数については、文 4)に示す報告、及びこれまでの本研究 室における実敛経一船越徽、積田洋：街路空間における空間意識の 分析（心理量分析）、日本建築学会論文報告集、pp.100 107、第 327 号、1983.5 などから 16 名とした。また、同じ被略者は重複して実睮 に参加していない。

注6）各カテコリーウェイトの值の高い/低いは、ミュージアム空間におけ る結果についてのみ考察している。また、文 4) の病院の研究で得られ たカテコリリーウェイトは次の通りである。X1:パーツが存在しない= $-0.57 、 \mathrm{X} 2$ : パーツの選択を䜋った $=-0.29 、 \mathrm{X} 3:$ パーツの裏表を間 違った $=-0.09 、 \mathrm{X} 4:$ パーツの接続位置が連う $=-0.48 、 \mathrm{X} 5:$ パーツ の接続向きが違う $=-0.49 、 \mathrm{X} 6$ : 余分なパーツが接続させている $=-0.47$ 病院の研究では、注 4) に示す通り、「パズルパーツの裏表」が存在し ていたため、病院空間とミュージアム空間では、カテゴリー数が连う ため、安易にを比校することは出来ないが、空間構成を把挃する上で 最も障害となる共通の要因として、存在すら把握できない空間、他の 空間の流れから全く切り放された不連続な空間が存在する場合である ことが分かる。

注 7）空間構成上重要であっても、その空間が被睎者に非常に把握されやす く、間虺いが少ないために、P.MAP 完成度評価に大きく影幚しないこ とから、重回埽你数が低くなる場合や、重要でなくとも間连いが多い ため、全体の空間構成を大きく変えてしまい、P.MAP 完成度評価が低 い値を示すために、重回帰保数が高くなる場合がある。この点に関し ては、それらを十分に考慮した上で分析を行っている。

（1998年 4 月 10 日原稿受理，1998年11月 12 日採用決定） 